\title{
Sustainable production of protein of animal origin - the state of knowledge. Part 2. Aquirements, objectives and ways of sustainbility improvement
}

\author{
G. Flachowsky and U. Meyer ${ }^{1}$ \\ Institute of Animal Nutrition, Friedrich-Loeffler-Institut (FLI), Federal Research Institute for Animal Health \\ Bundesallee 50, 38116 Braunschweig, Germany
}

KEY WORDS: plant, animal breeding, alternative feeds, protein sources, eating patterns, food looses

Received: 19 September 2015

Revised: 3 November 2015

Accepted: 29 November 2015

${ }^{1}$ Corresponding author:

e-mail: ulrich.meyer@fli.bund.de

\begin{abstract}
This part describes challenges to improving sustainability during the production of food of animal origin. Some potential advancements in the sustainability of producing food of animal origin, such as feeds that do not compete with human nutrition, plant and animal breeding, trends in animal nutrition, potential alternative protein sources, alternatives of animal products in nutrition, including lower food losses, are discussed in the paper. The potential for reducing gaseous emissions is also an important chapter in this contribution. Complex calculations employing parameters of efficient use of limited resources and reduction of emissions seem to be helpful in finding optimums in production of food of animal origin.
\end{abstract}

\section{Challenges to improving sustainability during production of food of animal origin}

There are currently many ways to overcome food deficiency and to produce food in more sustainable ways. More efficient animal nutrition, feed that is non-competitive with human nutrition (e.g., grassland, co-products of agriculture, food and biofuel industries (Makkar, 2012) or other biomasses), reduction of loss and waste in agriculture, food processing, trade and households, as well as in plant and animal breeding are the most promising (Niemann et al., 2011; Flachowsky et al., 2015). Other options, like the use of insects as food (EFSA, 2015) or other alternative foods, or changes in eating patterns are under discussion. More details are given in the following sections.

\section{Plant breeding}

Plant breeding can be considered the starting point of the food chain (Part 1; Figure 2) for sustainable plant (feed) production (SCAR, 2008; The Royal Society, 2009; Flachowsky et al., 2013a). It has a large and strategic potential for global feed and food security.

Developing high-yield, stable and highly digestible crops with low external inputs of non-renewable resources, such as water, fuel, arable land, fertilizers, etc., low emissions of gases with greenhouse potential during cultivation, high resistance against biotic and abiotic stressors, including adaptation to potential climate change (Reynolds, 2010; Newman et al., 2011; Fischer et al., 2014) and low concentrations of undesirable substances in the plants, are important challenges for plant breeders. Plants with these properties would allow more sustainable 
production in the future and would be important in human and animal nutrition. Such an ideal crop (Pennisi, 2010) may contribute to sustainable plant production. Additional aspects for plant breeders from the viewpoint of animal nutrition are:

- consideration of forages and grassland

- biofortification of plants is not so important because many feed additives is available

- the feed value of co-products after processing 'new' plants for food and biofuel

- recommended animal feeding studies with target animal species to evaluate the nutritional effects and safety of the changes induced in the plants (Flachowsky, 2013; Van Eenennaam and Young, 2014)

- cooperation between plant breeders and animal nutritionists in the early stages of breeding programmes.

Traditional breeding, as well as 'green' biotechnology ('green' chemistry, genetic engineering; Guillou and Matheron, 2014) can contribute to fulfilling the objectives mentioned above. Genetically modified plants may achieve these objectives faster and with greater precision (Tester and Langridge, 2010; Flachowsky, 2013), but are under critical public discussion presently. More activities and more publicsupported research in these fields are necessary for sustainable utilization of natural limited resources and for improved use of unlimited resources such as sun energy/light, $\mathrm{CO}_{2}$ and $\mathrm{N}_{2}$ from the air, or the global gene pool. All methods of plant breeding that contribute to more resource-efficient production of high and stable yields of available biomass should be used. Ruane et al. (2013) and Andersen et al. (2015) analysed new breeding techniques for organic farming and came to the conclusion that the most efficient methods are based on modern biotechnology techniques, which have yet to be embraced by the organic farm movement. In addition, the potential use of new breeding technologies in organic farming is limited in the EU, where the current regulatory framework is process based and would classify products produced using new technologies as genetically modified organisms (GMO). The question arises whether the adoption of biotechnological methods is feasible not only from the perspective of sustainability, but also from conceptual, socio-economic, ethical and regulatory perspectives.

\section{Animal breeding}

An important contribution to meet the increasing needs for food of animal origin and mitigating undesired effects in animal husbandry is to enhance the efficiency of animal growth, reproduction, lactation and laying performance (Wu et al., 2014a). The breeding of domestic animals has a longstanding and successful history, starting with domestication several thousand years ago, when man kept animals in his proximity and used products thereof. Using the technical options that were available in each time period, humans have propagated those populations that deemed useful for their respective needs and purposes. Selection mostly occurred according to desirable traits. Scientifically based animal breeding has only existed for about 50 years, supported mainly by population genetics and statistics.

Modern animal breeding programmes include biotechnological procedures, of which artificial insemination (AI) is the most prominent. Presently, AI is employed in more than $90 \%$ of all sexually mature female dairy cattle in countries with advanced breeding programmes. Strategies to breed animals that more efficiently process feed into animal-derived food and concomitantly decrease emission per product unit may contribute to more sustainable livestock production (Thornton, 2010; Niemann et al., 2011). The objectives of these strategies comprise:

- higher feed intake of animals (NRC, 1987; Forbes, 1995) to improve the ratio between energy/nutrient requirements for maintenance and animal yields (Part 1; Table 5)

- higher digestibility of feed (Tillie et al., 2013) to make energy and nutrients more available from the same amount of feed

- using the advantages of ruminants (Hungate, 1966; van Soest, 1994; Hobson and Stewart, 1997) and reduction of energy losses from the digestive tract, e.g., $\mathrm{CH}_{4}$ (Baldwin, 1995; Kebreab et al., 2006)

- higher absorption of the digested nutrients

- lower energy and nutrient requirements for maintenance of the animals

- lower energy needed for protein synthesis in the body

- stimulation of anabolic processes and decreasing catabolic processes in the animal

- lower fat content in animal bodies, lower excretion of fat in milk and eggs and of lactose in milk (lower energy content in products)

- improved animal health, specifically higher resistance against biotic and/or abiotic stressors and lower losses may contribute to longevity (e.g., of dairy cows) and more efficient conversion of feed.

In summary, the strategies discussed above show that breeding strategies may contribute to lower energy requirements of animals and to more efficient 
feed conversion. In the future, existing and emerging breeding technologies could be instrumental in producing livestock with much greater feed efficiency and in improving the sustainability of animal husbandry. Ruane et al. (2013) analysed 12 case studies of application of biotechnology in livestock and aquaculture and concluded that these techniques have great potential for improving on-farm productivity and living conditions of farmers.

\section{Contributions of animal nutrition}

Progress in feed science, nutritional physiology and animal feeding are important key elements for more efficient conversion of feed in food of animal origin and lower emissions per animal product (Flachowsky et al., 2013a; Makkar and Ankers, 2014). There are some strategies that contribute to this objective, such as:

- production, conservation and preparation of high quality feeds

- higher feed intake of animals to improve the ratio between energy/nutrient requirements for maintenance and animal yields (e.g., Niemann et al., 2011)

- better knowledge about animal requirements in essential nutrients (e.g., amino acids, minerals, vitamins) and supplementation of feed with adequate nutrients and some non-essential feed additives

- meeting the protein and amino acid requirements more precisely by ration calculation on the basis of adequate animal requirements (e.g., precaecal amino acids; GfE, 2008, 2014) and supplementation with amino acids

- supplementation with feed additives for better digestion and utilization of feeds or special nutrients in feed (availability of $\mathrm{P}$ from phytate-P with the enzyme phytase).

These and further measurements contribute to more efficient conversion of feed. For example, feed use per kilogram of egg mass decreased in Europe from 3.1 (1968) to below $2 \mathrm{~kg}$ (EU, 2008) or the phosphorus excretion of fattening pigs $(35-115 \mathrm{~kg}$ body weight) decreased from 625 (without phytase) to $350 \mathrm{~g}$ per animal with phytase supplementation (GfE, 2008). Wu et al. (2014a) analysed pork production in the United States between 1959 and 2009 and found improvement in the feed:gain ratio from 6.6 to $4.4 \mathrm{~kg} \cdot \mathrm{kg}^{-1}$ of dressed carcass, a decrease in the $\mathrm{CF}$ from 8.4 to $5.5 \mathrm{~kg}$ per kilogram dressed carcass and in the efficiency of land use from 365 to $1672 \mathrm{~kg}$ of dressed carcass per hectare. Feed efficiency can be considered a key driver of productivity, resource use and greenhouse gas (GHG) emissions (Herrero et al., 2013).
In relation to nutrient requirements and further improvement of feed efficiency, the NRC (2015) concluded that 'research should continue to develop a better understanding of nutrient metabolism and utilization in the animals and the effects of those nutrients on gene expression. A systems-based holistic approach needs to be utilized that involves ingredient preparation, understanding of ingredient digestion, nutrient metabolism and utilization through the body, hormonal controls and regulators of nutrient utilization. Of particular importance is basic and applied research in keeping knowledge of nutrient requirements of animals current.'

\section{Use of feeds that do not compete with human nutrition}

Some feeds such as grassland, co-products from agriculture, the food and biofuel industries, etc., do not compete with human nutrition. Therefore, they do not compete with arable land and further limited resources and have a large potential for animal nutrition.

Ruminants are generally independent from grains or concentrates because their rumen microbial population is capable of digesting plant fibre. They are able to produce edible protein as milk and meat from permanent meadows and pastures. Their advantages compared with non-ruminants are very often described (e.g., Hungate, 1966; van Soest, 1994) and will not be further discussed here. Pastoral systems may contribute to meeting human demand for food of animal origin, and are more efficient in producing food per unit of area of dryland than other forms of agricultural land used under such conditions (HLPE, 2012). Pastoralist are also efficient users of resources like manure (Powell et al., 2013). Because of the predominantly high fibre content of roughage from grassland and low animal yields, the methane emissions and carbon footprints (CFs) per kilogram edible protein may be higher under such extensive conditions (FAO, 2010; Gill et al., 2010); GHG mitigation measurements are, therefore, important (Hristov et al., 2013a,b; Opio et al., 2013).

Besides roughages and concentrates, not only co-products from agriculture, such as cereal straw, but also from food production and the biofuel industry are commonly used in animal feeding. Coproducts are by-products of main processes such as grain production (e.g., straw, stalks, husks), processing of raw products in the food industry (e.g., extracted oil meals from the oil industry, bran from cereal processing, beet pulp or bagasse from the sugar industry, animal co-products from milk, fish, or meat processing) or from the biofuel industry (e.g., dried distillers grains' with solubles called DDGS; cakes and meals from rape and other oil seeds). According 
to FAO (2010), between 10 and $50 \%$ of concentrate comes from co-products in various global regions. In some countries, up to $100 \%$ of concentrate may be based on co-products. Co-products are mostly inedible to humans and otherwise would be wasted or used for energy production. They are used in various amounts and proportions in animal diets. Cereal straws and other co-products rich in plant cell walls are poorly digestible and thus are poor energy and protein sources. They are fed to ruminants with low animal performance or to meet their maintenance requirements. In the nutrition of yielding ruminants they can be considered only as a source of fibre. They are not used in the feeding of non-ruminants.

Co-products from the food and fuel industries usually contain more nutrients not removed by processing than raw materials (e.g., protein in the case of DDGS). They can be used as valuable sources of protein, minerals and other nutrients, depending on the raw material and chemical or physical processing without any land footprint. In the future, more cereal grains will be used for food and fuel and more co-products will be available for animal nutrition. More details about the nutritive value and utilization of co-products from the biofuel industry in animal nutrition were recently compiled by Makkar (2012). Also some other biomasses such as algae, seaweed, duckweed, leaves and twigs of trees and shrubs, etc., do not compete with human nutrition and are used as animal feed (van der Spiegel et al., 2013).

The NRC (2015) concluded that 'research should continue to identify alternative feed ingredients that are inedible to humans and will notably reduce the cost of animal protein production while improving the environmental footprint. These investigations should include assessment of the possible impact of changes in the protein product on the health of the animal and the eventual human consumer, as well the environment.'

\section{Potential of insects and other protein sources}

Apart from developments in plant and animal breeding and nutrition, the utility of insects (e.g., Makkar et al., 2014; Morales-Ramos et al., 2014), molluscs, snails and microbial biomasses (Anupama and Ravindra, 2000; Zepka et al., 2010) are being studied as alternatives in order to stabilize and improve human and animal nutrition.

Presently, insects as feed and food are considered a 'hot topic' in Europe. Some European countries (e.g., Belgium, France, Iceland, the Netherlands) have performed risk assessments related to insects as food and feed. In May 2014, Wagenin- gen University (the Netherlands) organized in collaboration with the Food and Agricultural Organization of the United Nations (FAO) an international conference entitled Insects to Feed the World. The European Food Safety Authority (EFSA) submitted a Scientific Opinion on the 'Risk Profile Related to Production and Consumption of Insects as Food and Feed' (EFSA, 2015) and the Wageningen Academic Publishers started in 2015 to publish a scientific journal entitled Journal of Insects as Food and Feed.

More than 1900 insect species in various development stages (van Huis, 2013) are eaten by humans worldwide. The most commonly eaten insect groups are from the orders: Coleoptera (beetles), Lepidoptera (caterpillars of butterflies and moths), Hymenoptera (bees, wasps, ants), Orthoptera (grass - hoppers, locusts, crickets, termites), Hemiptera (cicadas, leaf and plant hoppers, true bugs, scale insects), Odonata (dragonflies) and Diptera (flies) (EFSA, 2015).

Because of the large variety of insects consumed, it is difficult to give a representative review of their nutritional composition. There are, however, some papers that summarize compositional data (Table 8). The chemical composition depends on the species and developmental stage (eggs, larvae, pupa, adults) and the diet fed to insects. Handling, preparing and processing of insects may also influence their composition and nutritive value (van Huis, 2013; Makkar et al., 2014; EFSA, 2015). In insects prepared for human consumption, wings, legs and gastrointestinal contents are often removed, possibly also due to different analytical approaches. Because the nutritional composition of insects is difficult to establish, only some general statements can be made. Table 8 shows the range of proximate compositions of insects according to different authors. Tryptophan, lysine and histidine are considered the most frequent limiting amino acids in insect proteins (Finke, 2004; Sanchez-Muros et al., 2014).

Notwithstanding tradition and ethical reasons, more research on the nutritive value and on the microbiological and chemical hazards of insects, insect products and other 'new' feeds and foods is necessary. Safety research should be also intensified when insects are growing on bio-wastes, including manure or in regions with undesirable substances in the food chain (EFSA, 2015).

\section{Alternatives to protein of animal origin}

Foods of plant origin with a high protein concentration such as grain-based products, legumes and nuts can replace animal protein in the human diet. The protein concentration varies among the different plant sources from approximately 10 to $30 \%$ (EFSA, 
Table 8. Examples of different insect species proximate body composition ranges by various authors (crude nutrients by Weender analysis; in $\%$ of dry matter)

\begin{tabular}{llcccc}
\hline Authors & No of samples, species & $\begin{array}{l}\text { Crude protein } \\
(\mathrm{N} \mathrm{x} \mathrm{6.25)}\end{array}$ & $\begin{array}{l}\text { Crude fat } \\
\text { (ether extract) }\end{array}$ & $\begin{array}{l}\text { Carbohydrates } \\
\text { (NFE', fibre, NDF² })\end{array}$ & $\begin{array}{l}\text { Crude } \\
\text { ash }\end{array}$ \\
\hline Rumpold and Schlüter, 2013 & 234 & $4.9-74.8$ & $0.7-67.2$ & $3.0-86.3$ & $0.6-26.0$ \\
Sanchez-Muros et al., 2014 & 72 & $9.5-70.1$ & $1.5-56.1$ & $1.8-77.7$ & $0.6-26.0$ \\
Makkar et al., 2014 & Black soldier fly larvae & $41.1-43.6$ & $15.0-34.8$ & 7.0 & $14.6-26.8$ \\
& Housefly maggot meal & $42.3-60.4$ & $9.0-26.0$ & $1.6-8.6$ & $6.2-17.3$ \\
& Tenebrio molitor & $47.2-60.3$ & $31.1-43.1$ & $7.4-15.0$ & $1.0-4.5$ \\
& Locust or grasshopper meal & $29.2-65.9$ & $4.2-14.1$ & $2.4-14.0$ & $4.4-10.0$ \\
& House cricket & $55.0-67.2$ & $9.8-22.4$ & $15.7-22.1$ & $3.6-9.1$ \\
& Silkworm pupae meal & $51.6-70.6$ & $6.2-37.1$ & $2.5-5.8$ & $3.3-10.6$ \\
\hline
\end{tabular}

${ }^{1} \mathrm{NFE}$ - N-free extractives, ${ }^{2} \mathrm{NDF}$ - neutral detergent fibre

2012; Day, 2013). There are some alternatives to protein of animal origin and initiatives have been taken to replace it in other ways and by producing similar products (e.g., soya milk, tofu, rice milk). Such food is usually produced from valuable protein sources of plant origin (e.g., soyabean, wheat, rice, maize, barley, pea, sorghum, lupine and chickpea). Developers try to create new meat and milk analogue products by combining proteins from various plant sources (Aiking, 2011; Day, 2013).

Cultured muscle cells (Dodson et al., 1997; Post, 2014) from bovine skeletal muscle stem cells produced beef with the same nutritional value as livestock and can also be an alternative to 'traditional' protein of animal origin. Protein synthesis by cultured skeletal muscle cells should be very efficient. Further studies including psychological obstacles concerning public acceptance are necessary for optimization of the protein and fat content of cultured beef. Research in this field is a great challenge for the future.

\section{Reducing food losses and changing eating patterns}

The issue of global food losses and wastes has recently received much attention. According to FAO (2013b), about one-third of food produced for human consumption - about 1.3 billion tones of edible food - is lost or wasted globally per year. This amount is the equivalent of about $24 \%$ of all the calories currently produced for human consumption (Lipinski et al., 2013). In developing countries, food waste and losses occur mainly in the early stages of the food chain; in medium- or high-income countries, food is wasted or lost mainly in later stages of the food chain (FAO, 2011). Reduction of these losses is essential for improving food security, sustainability of food production and for reducing the environmental footprint of food systems.
Recently HLPE (2014) analysed and summarized the reasons for food losses from the field to the consumer and gave the following recommendations to reduce these losses:

- improvement of data collection and sharing knowledge on food losses and waste

- development of effective strategies to reduce food losses and waste, at the appropriate levels

- implementation of effective steps to reduce food losses and waste

- better coordination of policies and strategies in order to reduce food losses and waste.

More details about reducing food losses and waste can be found in some recent papers and reviews (Parfitt et al., 2010; FAO, 2011; Lipinski et al., 2013; Blanke, 2015).

Human eating patterns may also influence the sustainability of agriculture and animal husbandry. Higher demand for food of animal origin as a result of growing incomes (Keyzer et al., 2005; Kastner et al., 2012) requires higher plant yields and/ or more area for feed production (Gerbens-Leenes and Nonhebel, 2002; Wirsenius et al., 2010), as well as more animals and/or higher animal yields and an increase in agricultural trade. Therefore, some authors propose a redefinition of agricultural yield and agriculture: 'from tons to people nourished per hectare' (Kastner et al., 2012; Cassidy et al., 2013) and ask for more sustainable animal agriculture (Kebreab, 2013; SAFA, 2013). On the other hand, changing eating patterns (Guyomard et al., 2012) and eating less or no livestock products, especially meat, are often seen as possible solutions to reducing the environmental impact of animal agriculture (Pimentel and Pimentel, 2003; Baroni et al., 2007) and per capita land requirements (Peters et al., 2007; Flachowsky et al., 2015) and should contribute to more sustainable animal production. 
Table 9. Feed measurements to reduce enteric methane emission, importance on farm level and research need in ruminants

\begin{tabular}{|c|c|c|}
\hline Measurements & $\begin{array}{l}\text { Significance (esp. for Europe) } \\
\text { on farm level }\end{array}$ & $\begin{array}{l}\text { Research } \\
\text { need }\end{array}$ \\
\hline \multicolumn{3}{|l|}{ Feeds and feeding } \\
\hline - more concentrate, less fibre in diet & $\begin{array}{l}\text { Limited, because of high concentrate amounts already } \\
\text { in many diets }\end{array}$ & $\sim$ \\
\hline - forages with high digestibility, low fibre content & Consideration in plant breeding and practical feeding & $\Uparrow$ \\
\hline - fats and fatty acids in diets & Limited, because of some side effects in the rumen & $\Uparrow$ \\
\hline \multicolumn{3}{|l|}{ Application of feed additives } \\
\hline - halogen compounds (e.g., chloral hydrates) & Banned in the EU & $\sim$ \\
\hline - Ionophores (e.g., monensin) & Banned in the EU & $\Uparrow$ \\
\hline - addition of hydrogen acceptors, such as fumaric acid, acrylic acid, etc. & Presently no significance & $\Uparrow$ \\
\hline $\begin{array}{l}\text { - addition of phytogenic substances (essential oils; plant extracts } \\
\text { or plants containing such substances, e.g., garlic); tannins; saponines }\end{array}$ & Presently no significance & $\Uparrow \Uparrow$ \\
\hline - addition of 3-nitrooxypropanol and other nitrooxy carboxylic acids & Presently no significance & $\Uparrow \Uparrow$ \\
\hline - further additives, such as yeasts, enzymes, etc. & Presently no significance & $\Uparrow$ \\
\hline Selection of ruminant species with low $\mathrm{CH}_{4}$ emission & Presently no significance & $\Uparrow \Uparrow$ \\
\hline
\end{tabular}

$\Uparrow \Uparrow$ - high need; $\Uparrow$ - need; - not so important

\section{Reduction of emissions}

As already mentioned (Part 1), methane $\left(\mathrm{CH}_{4}\right)$ is the most important GHG associated with animal husbandry coming directly from animals (e.g., Hristov et al., 2013a), from excrement management (Hristov et al., 2013b; Montes et al., 2013), or from land use changes (Rounsevell et al., 2012; Havlik et al., 2013). Carbon dioxide $\left(\mathrm{CO}_{2}\right)$ from animal metabolisms will be recycled by plant growth (Part 1, Figure 2) and nitrous oxide (laughing gas, $\mathrm{N}_{2} \mathrm{O}$ ) is not directly excreted by animals (see Part 1). Therefore, the possibilities of reducing methane emissions (Part 1, Methane $\left(\mathrm{CH}_{4}\right)$ ) will be discussed below.

Some possibilities for reducing methane emission in ruminants, such as increasing forage digestibility and digestible forage intake, dietary lipids, higher dietary concentrate proportions, or the application of various feed additives are shown in Table 9 and are mentioned by some authors (e.g., Blaxter and Czerkawski, 1966; Beauchemin et al., 2009). Potential reduction strategies have been grouped in three complexes in Table 9:

- effects of feeds/feeding/ration composition

- ration supplementation with feed additives

- selection of ruminant species.

GHG emissions can be reduced by increasing animal productivity and feed efficiency using metabolic modifiers, such as growth hormones and ionophoric antibiotics, but the applicability of these mitigation practices is limited to regions where their use is permitted. Ranga Niroshan Appuhamy et al. (2013) have analysed the data from 22 controlled feeding studies on the potential of methane reduction by the ionophoric substance, monensin.
Its mitigation effects were small (12 or $14 \mathrm{~g} \cdot \mathrm{d}^{-1}$ in dairy cows and beef cattle) when adjusted for dose.

Hydrogen acceptors, such as fumaric acid, acrylic acid and other substances may also contribute to $\mathrm{H}_{2}$-binding in the rumen, but the in vivo effects are small and inconsistent (Bayaru et al., 2001; Remling et al., 2014).

Many studies have been done with substances of plant origin such as tannins, non-tannins, phenols, saponins, essential oils, and whole plants or parts of plants. The development of new feed additives, mainly based on plant extracts, to decrease methane production within the rumen has attracted much research over the last 20 years. The results remain variable and contradictory, as summarized by Benchaar and Greathead (2011). The effects of plants or plant extracts having a high content of saponins, flavonoids and tannins varied depending upon the source, type and level of secondary metabolites present in the plant material. These may limit the demand and use of such substances in the animal feed market for reasons related to several factors, including the lack of persistency of the effects when they are tested in vivo due to the adaptation of the microbial ecosystem, the variability of concentration of active compounds in plant extracts, the stability of the active substance within the rumen, and possible side effects that compromise overall rumen fermentation (Hart et al., 2008).

Most of the substances were tested in in vitro studies and they may have a potential to reduce methane emissions from ruminants, although their long-term effects have not been well established and some are toxic or may not be economically feasible. Impressive results of in vitro studies were mostly 
not repeated under in vivo conditions. Therefore, Flachowsky and Lebzien (2012) proposed a five stage programme to evaluate the effects of such additives, with special consideration of phytogenic substances:

- botanical characterization of the plant(s) and their composition

- analytical characterization of the active phytogenic substance(s)

- in vitro studies to test effects of substances on rumen fermentation and methanogenesis (i.e. screening)

- in vivo studies comprising feed intake, rumen fermentation and $\mathrm{CH}_{4}$ emissions

- long-term feeding studies with target animal species/categories (animal health and performance, quality and safety of food of animal origin, environmental impact, adaptation of microbes).

Another reason for the restricted use of phytogenic substances as methane inhibitors may be their potential transfer from feed into food of animal origin and possible residues in animal products and their effects in humans (EFSA, 2009; Speijers et al., 2010).

The development of synthetic compounds with specific activities to influence metabolic pathways essential to ruminal archaea may overcome some drawbacks of phytogenic compounds. Inhibition of methyl-coenzyme $\mathrm{M}$ reductase which catalyses the last step of reduction of $\mathrm{CO}_{2}$ to $\mathrm{CH}_{4}$ by hydrogenotrophic methanogenic archaea (Attwood and McSweeney, 2008) has been studied extensively. In preliminary studies by Martínez-Fernández et al. (2013) and Romero Perez et al. (2013), the authors tested the effects of inhibitors of methyl-coenzyme $\mathrm{M}$ reductase, such as nitrooxy propionate compounds on ruminal fermentation and methane emissions. These substances are able to reduce the final step of $\mathrm{CO}_{2}$ to $\mathrm{CH}_{4}$ by methanogenic archaea (Duval and Kindermann, 2012). Martínez-Fernández et al. (2014) studied the effect of ethyl-3-nitrooxy propionate (E3NP) and 3-nitrooxypropanol (3NP) in vitro and in vivo in non-lactating sheep on ruminal methane production, fermentation pattern, abundance of major microbial groups and feed degradability. In an in vitro batch culture trial, substantial reduction of methane production (up to $95 \%$ ) without affecting the concentration of volatile fatty acids was found. Methane production in sheep decreased by $29 \%$ without any effect on rumen dry matter degradation in comparison with the unsupplemented control.

Reynolds et al. (2014) tested the effects of feeding two doses of $3 \mathrm{NP}$ on methane emissions, digestion and on the energy and nitrogen balance of lactating cows. The substance was administered through a rumen fistula. Daily methane production was reduced by $6.6 \%$ and $9.8 \%$ for 0.5 and $2.5 \mathrm{~g}$ of $3 \mathrm{NP} \cdot \mathrm{d}^{-1}$, respectively. Homogenous mixing with feed or a slow-release bolus may be effective ways of application. Haisan et al. (2014) applied 2.5 g 3NP (per cow and day) by hand-mixing into the total mixed ration (TMR) and found a reduction of methane emission by about $60 \%$ without a significant effect on dry matter intake, milk yield or milk composition. The additive increased body weight gain, indicating that the reduction of methane emissions increased energy availability to animals. Further studies are needed to understand the mode of action of 3NP in the rumen (Flachowsky and Lebzien, 2012).

\section{Conclusions}

Sustainability of the production of food of animal origin requires a comprehensive approach. Improvement of particular segments of the food chain does not essentially improve the whole system. Increase of farm animal productivity or feed efficiency may also decrease the emissions of gases and the contamination of soils and water per unit of food of animal origin.

More complex calculations when it comes to parameters of efficient use of limited resources and reduction of emissions seem to be helpful in finding an optimum in production of food of animal origin. The following parameters should be considered in future calculations:

- use of arable land (competition between various users)

- efficient use of water for feed and animal production

- minimization of the use of fuel and other limited natural resources in the food chain

- utilization of permanent grassland and co-products from agriculture and industry

- feed efficiency as a key driver of productivity, resource use, and greenhouse gas emissions

- reduction of greenhouse gas emissions per product or per kilogram edible protein and along the entire food chain

- conservation of biodiversity

- plant and animal breeding as the starting points of the human food chain

- comparison of production of food of animal origin with other protein sources, including vegetarian foods (e.g., milk, meat based on soyabeans)

- calculation of land use per inhabitant accounting for the eating patterns of the population; changing eating patterns

- reduction of food wastage. 
Producing food of animal origin is a very complex process. Cooperation among animal scientists (nutritionists, breeders, animal keepers/farmers, veterinarians, etc.) with scientists working in the fields of plant and feed science, ecology and economy seems to be necessary to solve the problems and to develop better and reliable land footprints.

In summary, more (food) for more (people) with less (resources and emissions) is one of the most important challenges for all those involved in feed/ food science and production.

Public funding of plant and animal research may be considered an important challenge for meeting future animal protein demand (NRC, 2015) and improving sustainability along the entire food chain.

\section{References}

Aerts S., 2012. Agriculture's 6 Fs and the need for more intensive agriculture. In: T. Potthast, S. Meisch (Editors). Climate Change and Sustainable Development. Wageningen Academic Publishers. Wageningen (the Netherlands), pp. 192-195

Aiking H., 2011. Future protein supply. Trends Food Sci. Tech. 22, $112-120$

Allouche J., 2011. The sustainability and resilience of global water and food systems: Political analysis of the interplay between security, resource scarcity, political systems and global trade. Food Policy 36, Suppl. 1, S3-S8

Andersen G., 2011. Food table for the practice: The little Souci-Fachmann-Kraut (in German). Wissenschaftliche Verlagsgesellschaft $\mathrm{mbH}$. Stuttgart (Germany)

Andersen M.M., Landes X., Xiang W. et al., 2015. Feasibility of new breeding techniques for organic farming. Trends Plant Sci. 20, 426-434

Anupama, Ravindra P., 2000. Value-added food: single cell protein. Biotechnol. Adv. 18, 459-479

Attwood G., McSweeney C., 2008. Methanogen genomics to discover targets for methane mitigation technologies and options for alternative $\mathrm{H}_{2}$ utilisation in the rumen. Aust. J. Exp. Agr. 48, 28-37

Avadí A., Fréon P., 2013. Life cycle assessment of fisheries: A review for fisheries scientists and managers. Fish. Res. 143, 21-38

Baldwin R.L. (Editor), 1995. Modeling Ruminant Digestion and Metabolism. Chapman \& Hall. London (UK), pp. 578

Bannink A., France J., Lopez S., Gerrits W. J. J., Kebreab E., Tamminga S., Dijkstra J., 2008. Modelling the implications of feeding strategy on rumen fermentation and functioning of the rumen wall. Anim. Feed Sci. Tech. 143, 3-26

Baroni L., Cenci L., Tettamanti M., Berati M., 2007. Evaluating the environmental impact of various dietary patterns combined with different food production systems. Eur. J. Clin. Nutr. 61, 279-286

Bayaru E., Kanda S., Kamada T., Itabashi H., Andoh S., Nishida T., Ishida M., Itoh T., Nagara K., Isobe Y., 2001. Effect of fumaric acid on methane production, rumen fermentation and digestibility of cattle fed roughage alone. Anim Sci J. 72, 139-146

Beauchemin K.A., McAllister T.A., McGinn S.M., 2009. Dietary mitigation of enteric methane from cattle. CAB Reviews. Perspect Agric. Vet. Sci. Nutr. Nat. Res. 4, 1-18
Benchaar C., Greathead H., 2011. Essential oils and opportunities to mitigate enteric methane emissions from ruminants. Anim. Feed Sci. Tech. 166-167, 338-355

Bessou C., Mary B., Léonard J., Roussel M., Gréhan E., Gabrielle B., 2010. Modelling soil compaction impacts on nitrous oxide emissions in arable fields. Eur. J. Soil Sci. 61, 348-363

Blanke M., 2015. Challenges of reducing fresh produce waste in Europe - from farm to fork. Agriculture 5, 389-399

Blaxter K.L., Czerkawski J., 1966. Modifications of the methane production of the sheep by supplementation of ITS diet. J. Sci. Food Agric. 17, 417-421

Bockisch F.J., Ahlgrimm H.J., Böhme H. et al., 2000. Evaluation of organic and conventional agriculture concerning energy input and greenhouse gas emission output (in German). Landbauforsch Volk SH 211. Braunschweig (Germany), pp. 206

Boonen R., Aerts S., De Tavernier J., 2012. Which sustainability suits you? In: T. Potthast, S. Meisch (Editors). Climate Change and Sustainable Development. Wageningen Academic Publishers. Wageningen (the Netherlands), pp. 43-48

Bruinsma J., 2009. The resource outlook to 2050: by how much do land, water and crop yields need to increase by 2050? In: How to Feed the World in 2050. Proceedings of a Technical Meeting of FAO Experts. Rome (Italy), pp. 1-33

Brundtland G.H., 1987. Our common future - call for action. Environ. Conserv. 14, 291-294

Casabona C.M.R., Epifanio L.E.S., Cirion A.E. (Editors), 2010. Global Food Security: Ethical and Legal Callenges. Wageningen Academic Publishers. Wageningen (the Netherlands), pp. 532

Cassidy E.S., West P.C., Gerber J.S., Foley J.A., 2013. Redefining agricultural yields: from tonnes to people nourished per hectare. Environ. Res. Lett. 8, pp. 8, doi:10.1088/1748-9326/8/3/034015

Day L., 2013. Proteins from land plants - Potential resources for human nutrition and food security. Trends Food Sci. Tech. 32, 25-42

de Alvarenga R.A.F., de Silva Júnior V.P., Soares S.R., 2012. Comparison of the ecological footprint and a life cycle impact assessment method for a case study on Brazilian broiler feed production. J. Clean. Prod. 28, 25-32

de Vries M., de Boer I.J.M., 2010. Comparing environmental impacts for livestock products: A review of life cycle assessments. Livest. Sci. 128, 1-11

Dodson M.V., Vierck J.L., Hossner K.L., Byrne K., McNamara J.P., 1997. The development and utility of a defined muscle and fat coculture system. Tissue Cell 29, 517-524

Duval S., Kindermann M., 2012. Nitrooxy alkanoic acids and derivates thereof in feed for reducing methane emission in ruminants, and/or to improve ruminant performance. S. Duval and M. Kindermann, assignees. US Patent No. 20, 120, 315, 339

EFSA, 2009. Guidance on safety assessment of botanicals* and botanical preparations ${ }^{* *}$ intended for use as ingredients in food supplements. EFSA J. 7, 1249, pp. 19

EFSA, 2012. Scientific opinion on dietary reference values for protein. EFSA J. 10, 2557, pp. 66

EFSA, 2015. Risk profile related to production and consumption of insects as food and feed EFSA J. 13, 4257, pp. 60

EU, 2008. Eurostatistics. Europäische Union; Annual Report

FAO, 2006. Livestock's long shadow. Environmental issues and options. FAO, Rome, pp. 406

FAO, 2009. How to feed the world in 2050. FAO, Rome, pp. 35

FAO, 2010. Greenhouse gas emissions from the dairy sector. A Life Cycle Assessment. FAO, Rome, pp. 94

FAO, 2011. Global food losses and food waste. FAO, Rome, 30

FAO, 2013a. FAO Statistical Yearbook. World food and agriculture. FAO, Rome, pp. 289 
FAO, 2013b. Food loss and waste: Definition and scope. FAO, Rome

FAO, 2014. The state of food insecurity in the world 2014. Strengthering the enabling environments for food security and nutrition. FAO, Rome, pp. 55

FAO, 2015. Estimating greenhouse gas emissions in agriculture. A manual to address data requirements for developing countries. FAO, Rome, pp. 180

Fedoroff N.V., Battisti D.S., Beachy R.N. et al., 2010. Radically rethinking agriculture for the 21 st century. Science $327,833-834$

Finke M.D., 2004. Nutrient Content of Insects - Organic Value Recovery Solution Studies. Encyclopedia of Entomology No. 10.1007/0306-48380-7_2920. Springer Verlag

Fischer T., Byerlee D., Edmeades G. (Editors), 2014. Crop Yields and Global Food Security: Will Yield Increase Continue to Feed the World? Australian Centre for International Agricultural Research (ACIAR). Canbera (Australia), pp. 634

Flachowsky G., 2002. Efficiency of energy and nutrient use in the production of edible protein of animal origin. J. Appl. Anim. Res. 22, 1-24

Flachowsky G. (Editor), 2013. Animal Nutrition with Transgenic Plants. CAB International. Wallingford (UK), pp. 234

Flachowsky G., 2015. Carbon footprints for food of animal origin. In: P.K. Malik, R. Bhatta, J. Takahashi (Editors). Livestock Production and Climate Change. CAB International. Wallingford (UK), pp. 125-145

Flachowsky G., Gruen M., Meyer U., 2013a. Feed-efficient ruminant production: opportunities and challenges. J. Anim. Feed Sci. 22, 177-187

Flachowsky G., Hachenberg S., 2009. $\mathrm{CO}_{2}$ footprints for food of animal origin - present stage and open questions. J. Verbr. Lebensm. 4, 190-198

Flachowsky G., Kamphues J., 2012. Carbon footprints for food of animal origin: what are the most preferable criteria to measure animal yields? Animal 2, 108-126

Flachowsky G., Lebzien P., 2012. Effects of phytogenic substances on rumen fermentation and methane emissions: A proposal for a research process. Anim. Feed Sci. Tech. 176, 70-77

Flachowsky G., Meyer U., Gruen M., 2013b. Plant and animal breeding as starting points for sustainable agriculture In: E. Lichtfouse (Editor). Sustainable Agriculture Reviews. Vol. 12. Springer Science + Buisness. Dordrecht (the Netherlands), pp. 201-224

Flachowsky G., Meyer U., Südekum K.-H., 2015. Land use for edible protein of animal origin - A review. Food Security (submitted)

Flachowsky G., Schulz E., 2011. Sustainability in animal feeding (in German). Annual Book 'Mühle and Mischfutter', pp. 189-209

Foley J.A., Ramankutty N., Brauman K.A. et al., 2011. Solutions for a cultivated planet. Nature 478, 337-342

Forbes J.M. (Editor), 1995. Voluntary Food Intake and Dietary Selection in Farm Animals. CAB International. Wallingford (UK), pp. 453

Gahukar R.T., 2011. Entomophagy and human food security. Int. J. Trop. Insect. Sci. 31, 129-144

Garnett T., Röös E., Little D., 2015. Lean, green, mean, obscene...? What is efficiency? And it is sustainable? Food Climate Research Network; Environmental Change. Institute \& The Oxford Martin Programme on the Future of Food. University of Oxford (UK)

GASL (Global Agenda for Sustainable Livestock). 2014. Towards sustainable livestock (available at http://www.livestockdialogue. org/fileadmin/templates/res_livestock/docs/2014_Colombia/2014_Towards_Sustainable_Livestock-dec.pdf)

Gerbens-Leenes P.W., Nonhebel S., 2002. Consumption patterns and their effects on land required for food. Ecol. Econ. 42, 185-199
Gerbens-Leenes W., Hoekstra A.Y., van der Meer T.H., 2009. The water footprint of bioenergy. Proc. Nat. Acad. Sci. USA 106, 10219-10223

Gerber P.J., Steinfeld H., Henderson B., Mottet A., Opio C., Dijkman J., Falcucci A., Tempio G., 2013. Tackling climate change through livestock - A global assessment of emissions and mitigation opportunities. FAO, Rome, pp. 116

GfE, 1995. Recommendations for Energy and Nutrient Requirements of Beef Cattle (in German). No. 6. In: Energy and Nutrient Requirements of Domestic Animals. DLG-Verlags-GmbH. Frankfurt (Germany), p. 85

GfE, 1999. Recommendations for Energy and Nutrient Requirements of Laying Hens and Broilers (in German). No. 7. In: Energy and Nutrient Requirements of Domestic Animals. DLG-Verlags$\mathrm{GmbH}$. Frankfurt (Germany), pp. 185

GfE, 2001. Recommendations for Energy and Rutrient Requirements of Dairy Cattle and Heifers (in German). No. 8. In: Energy and Nutrient Requirements of Domestic Animals. DLG-Verlags-GmbH. Frankfurt (Germany), pp. 136

GfE, 2008. Recommendations for the Supply of Energy and Nutrients to Pigs (in German). In: Energy and Nutrient Requirements of Domestic Animals. DLG-Verlags-GmbH. Frankfurt (Germany), pp.180

GfE, 2014. Recommendations for the Supply of Energy and Nutrients of Horses (in German). DLG-Verlags-GmbH. Frankfurt (Germany), p. 192

Gill M., Smith P., Wilkinson J. M., 2010. Mitigating climate change: the role of domestic livestock. Animal 4, 323-333

Giovannucci D., Scherr S., Nierenberg D., Hebebrand C., Shapiro J., Milder J., Wheeler K., 2012. Food and Agriculture: the future of sustainability. A strategic input to the sustainable development in the $21^{\text {st }}$ Century (SD21) project. New York: United Nations Department of Economic and Social Affairs, Division for Sustainable Development, pp. 94

Gordon L.J., Finlayson C.M., Falkenmark M., 2010. Managing water in agriculture for food production and other ecosystem services. Agr. Water Manage 97, 512-519

Guillou M., Matheron G. (Editors), 2014. The World's Challenge - Feeding 9 Billion People. Éditions Quæ. Versailles (France), pp. 226

Guyomard H., Darcy-Vrillon B., Esnouf C., Marin M., Russel M., Guillou M., 2012. Eating patterns and food systems: critical knowledge requirements for policy design and implementation. Agric. Food Secur. doi:10.1186/2048-7010-1-13, pp. 13

Guyomard H., Manceron S., Peyraud J.L., 2013. Trade in feed grains, animals, and animal products: current trends, future prospects, and main issues. Anim. Front. 3, 14-18

Haddad L., Achadi E., Bendech M.A. et al., 2015. The Global Nutrition Report 2014: Actions and accountability to accelerate the world's progress on nutrition. J. Nutr. 145, 663-671

Haisan J., Sun Y., Guan L.L., Beauchemin K.A., Iwaasa A., Duval S., Barreda D.R., Oba M., 2014. The effects of feeding 3-nitrooxypropanol on methane emissions and productivity of $\mathrm{Hol}-$ stein cows in mid lactation. J. Dairy Sci. 97, 3110-3119

Hall D.C., Hall J.V., 1984. Concepts and measures of natural-resource scarcity with a summary of recent trends. J. Environ. Econ. Manage 11, 363-379

Hanjra M.A., Qureshi M.E., 2010. Global water crisis and future food security in an era of climate change. Food Policy 35, 365-377

Hart K.J., Yanez-Ruiz D.R., Duval S.M., McEwan N.R., Newbold C.J., 2008. Plant extracts to manipulate rumen fermentation. Anim. Feed Sci. Tech. 147, 8-35 
Havlik P., Valin H., Mosnier A., Obersteiner M., Baker J.S., Herrero M., Rufino M.C., Schmid E., 2013. Crop productivity and the global livestock sector: Implications for land use change and greenhouse gas emissions. Amer. J. Agr. Econ. $95,442-448$

Hergoualc'h K., Verchot L.V., 2011. Stocks and fluxes of carbon associated with land use change in Southeast Asian tropical peatlands: A review. Global Biogeochem. Cycles 25, GB2001; doi/10.1029/2009GB003718/

Herrero M., Havlik P., Valin H., Notenbaert A., Rufino M.C., Thornton P.K., Blümmel M., Weiss F., Grace D., Obersteiner M., 2013. Biomass use, production, feed efficiencies, and greenhouse gas emissions from global livestock systems. Proc. Nat. Acad. Sci. USA. 10, 20888-20893; doi: 10.1073/pnas.1308149110

HLPE, 2012. Food security and climate change. A report by the High Level Panel of Experts on Food Security and Nutritionof the Committee on World Food Security. Rome, pp. 98

HLPE, 2014. Food losses and waste in the context of sustainable food systems. A report by the High Level Panel of Experts on Food Security and Nutrition of the Committee on World Food Security. HPLE Report 8. Rome, pp. 116

HLPE, 2015. Sustainable agricultural development for food security and nutrition, including the role of livestock. Draft of the report; www.fao.org/cfs/cfs-hlpe

Hobson P.N., Stewart C.S. (Editors), 1997. The Rumen Microbial Ecosystem. Blackie Academic \& Profesional, an inprint of Chapman \& Hall. London (UK)

Hoekstra A.Y., Chapagain A.K., 2007. Water footprints of nations: Water use by people as a function of their consumption pattern. Water Resour. Manage 21, 35-48

Hoekstra A.Y., Hung P.Q., 2005. Globalisation of water resources: international virtual water flows in relation to crop trade. Global Environ. Change 15, 45-56

Hristov A.N., Oh J., Firkins J.L. et al., 2013a. Mitigation of methane and nitrous oxide emissions from animal operations: A review of enteric methane mitigation options. J. Anim. Sci. 91, 5045-5069

Hristov A. N., Ott T., Tricarico J. et al., 2013b. Mitigation of methane and nitrous oxide emissions from animal operations: III A review of animal management mitigation options. J. Anim. Sci. 91, 5095-5113

Hungate R.E. (Editor), 1966. The Rumen and its Microbes. Academic Press. New York (USA), pp. 533

IPCC (Intergovernmental Panel on Climate Change), 2006. 2006 IPCC Guidelines for National Greenhouse Gas Inventories, Prepared by the National Greenhouse Gas Inventories Programme. H.S. Eggleston, L. Buendia, K. Miwa, T. Ngara, Tanabe K. (Editors). IGES, Japan

IPCC (Intergovernmental Panel on Climate Change), 2014. Climate Change 2014: Mitigation of Climate Change. Contribution of Working Group III to the Fifth Assessment Report of the Intergovernmental Panel on Climate Change. (O. Edenhofer, R. Pichs-Madruga, Y. Sokona et al. (Editors). Cambridge University Press. Cambridge, United Kingdom and New York (USA)

IUCN (International Union for Conservation of Nature), 2004. The IUCN Programme 2005-2008. Many Voices, One Earth. Bangkok (Thailand). Available at: https://portals.iucn.org/library/sites/library/files/documents/WCC-3rd-002.pdf

Jackson A.A., 2007. Protein. In: J. Mann, S. Truswell (Editors). Essentials of Human Nutrition. $3^{\text {rd }}$ Edition. Oxford University Press (USA), pp. 53-72

Johnson K.A., Johnson D.E., 1995. Methane emissions from cattle. J. Anim. Sci. 73, 2483-2492
Jouany J.P., 2008. Enteric methane production by ruminants and its control. In: S. Andrieu, D. Wilde (Editors). Gut Efficiency: The Key Ingredient in Ruminant Production. Elevating Animal Performance and Health. Wageningen Academic Publishers. Wageningen (the Netherlands), pp. 35-59

Kastner T., Rivas M.J., Koch W., Nonhebel S., 2012. Global changes in diets and the consequences for land requirements for food. Proc. Nat. Acad. Sci. USA 109, 6868-6872

Kebreab E. (Editor), 2013. Sustainable Animal Agriculture. CAB International, Wallingford (UK), pp. 321

Kebreab E., Clark K., Wagner-Riddle C., France J., 2006. Methane and nitrous oxide emissions from Canadian animal agriculture: A review. Can. J. Anim. Sci. 86, 135-158

Keyzer M.A., Merbis M.D., Pavel I.F.P.W., van Wesenbeeck C.F.A., 2005. Diet shifts towards meat and the effects on cereal use: can we feed the animals in 2030? Ecol. Econ. 55, 187-202

Lampe C., Dittert K., Sattelmacher B., Wachendorf M., Loges R., Taube F., 2006. Sources and rates of nitrous oxide application of $\mathrm{N}$-15-labelled emissions from grazed grassland after mineral fertilizer and slurry. Soil Biol. Biochem. 38, 2602-2613

Lawrence D., Beddington J., Godfray C., Crute I., Haddad L., Muir J., Pretty J., Robinson S., Toulmin C., 2011. The challenge of global food sustainability. Food Policy 36, Suppl. 1, S1-S2

Lesschen J.P., van den Berg M., Westhoek H.J., Witzke H.P., Oenema O., 2011. Greenhouse gas emission profiles of European livestock sectors. Anim. Feed Sci. Tech. 166-167, 16-28

Lipinski B., Hanson C., Lomax J., Kitinoja L., Waite R., Searchinger T., 2013. Reducing Food Loss and Waste. Working Paper, Installment 2 of Creating a Sustainable Food Future. World Resources Institute. Washington, DC. Available online at http://www.worldresourcesreport.org

Lundy M.E., Parrella M.P., 2015. Crickets are not a Freelunch: protein capture from scalable organic side-streams via high-density populations of Acheta domesticus. PloS One 10, e0118785

MacLeod M., Gerber P., Mottet A., Tempio G., Falcucci A., Opio C., Vellinga T., Henderson B., Steinfeld H., 2013. Greenhouse gas emissions from pig and chicken supply chains - A global life cycle assessment. FAO, Rome, pp. 196

Makkar H.P.S., 2012. Biofuel co-products as livestock feed - opportunities and challenges. FAO, Rome, pp. 533

Makkar H.P.S., Ankers P., 2014. Towards sustainable animal diets: A survey-based study. Anim. Feed Sci. Tech. 198, 309-322

Makkar H.P.S., Tran G., Heuze V., Ankers P., 2014. State-of-the-art on use of insects as animal feed. Anim. Feed Sci. Tech. 197, $1-33$

Malik P.K., Bhatta R., Takahashi J., Kohn R.A., Prasad C.S., 2015. Livestock Production and Climate Change. CAB International. Wallingford (UK), pp. 395

Martínez-Fernández G., Abecia L., Arco A., Cantalapiedra-Hijar G., Martín-García A.I., Molina-Alcaide E., Kindermann M., Duval S., Yáñez-Ruiz D.R., 2014. Effects of ethyl-3-nitrooxy propionate and 3-nitrooxypropanol on ruminal fermentation, microbial abundance, and methane emissions in sheep. J. Dairy Sci. 97, 3790-3799

Martínez-Fernández G., Acro A., Abecia L., Cantalapiedra-Hijar G., Molina-Alcaide A., Martin-Garcia I., Kindermann M., Duval S., Yanez-Ruiz D.R., 2013. The addition of ethyl-3-nitrooxy propionate and 3-nitrooxypropanol in the diet of sheep substantially reduces methane emissions and the effect persists over a month. Adv. Anim. Biosci. 4, 368 (Abstr.)

McKenzie F.C., Williams J., 2015. Sustainable food production: constraints, challenges and choices to 2050. Food Security 7 , pp. 221-233 
Meadows D.L., Meadows D.H., Zahn E., Milline P. (Editors), 1972. Die Grenzen des Wachstums. Bericht des Club of Rome zur Lage der Menschheit. Deutsche Verlags-Anstalt (Germany)

Mekonnen M.M., Hoekstra A.Y., 2010. The green, blue and grey water footprint of farm animals and animal products. Value of Water Research Report Sereries No. 48, UNESCO-IHE. Delft (the Netherlands)

Meyer U., Everinghoff M., Gädeken D., Flachowsky G., 2004. Investigations on the water intake of lactating dairy cows. Livest. Prod. Sci. 90, 117-121

Meyer U., Stahl W., Flachowsky G., 2006. Investigations on the water intake of growing bulls. Livest. Sci. 103, 186-191

Molden D. (Editor), 2007. Water for Food, Water for Life: A Comprehensive Assessment of Water Management in Agriculture. Earthscan. London (UK), pp. 645

Molden D., Oweis T., Steduto P., Bindraban P., Hanira M.A., Kijne J., 2010. Improving agricultural water productivity: Between optimism and caution. Agr. Water Manage 97, 528-535

Montes F., Meinen R., Dell C. et al., 2013. Special topics-Mitigation of methane and nitrous oxide emissions from animal operations: II. A review of manure management mitigation options. J. Anim. Sci. 91, 5070-5094

Morales-Ramos J.A., Rojas M.G., Shapiro-llan D. (Editors), 2014. Mass Production of Beneficial Organisms - Invertebrates and Entomopathogens. Academic Press. Elsevier. London (UK), pp. 712

Mungkung R., Aubin J., Prihadi T.H., Slernbrouck J., van der Werf H.M.G., Legendre M., 2013. Life cycle assessment for environmentally sustainable aquaculture management: a case study of combined aquaculture systems for carp and tilapia. J. Clean. Prod. 57, 249-256

Newman J.A., Anand M., Henry H.A.L., Hunt S., Gedalof Z. (Editors), 2011. Climate Change Biology. CAB International. Wallingford (UK), pp. 289

Niemann H., Kuhla B., Flachowsky G., 2011. Perspectives for feedefficient animal production. J. Anim. Sci. 89, 4344-4363

Nijdam D., Rood T., Westhoek H., 2012. The price of protein: Review of land use and carbon footprints from life cycle assessments of animal food products and their substitutes. Food Policy 37 , 760-770

NRC, 1987. Predicting Feed Intake of Food Producing Animals. The National Academies Press. Washington, DC, pp. 96

NRC, 2015. Critical Role of Animal Science Research in Food Security and Sustainability. The National Academic Press. Washington, DC, pp. 436

Oonincx D.G., de Boer I.J., 2012. Environmental impact of the production of mealworms as a protein source for humans - a life cycle assessment. PloS one 7, e51145

Oonincx D.G., van Itterbeeck J., Heetkamp M.J., van den Brand H., van Loon J.J., van Huis A., 2010. An exploration on greenhouse gas and ammonia production by insect species suitable for animal or human consumption. PloS one 5, e14445

Opio C., Gerber P., Mottet A., Falcucci A., Tempio G., MacLeod M., Vellinga T., Henderson B., Steinfeld H., 2013. Greenhouse gas emissions from ruminant supply chains - A global life cycle assessment. FAO, Rome, pp.191

Parfitt J., Barthel M., Macnaughton S., 2010. Food waste within food supply chains: quantification and potential for change to 2050. Philos. Trans Roy. Soc. London B 365, 3065-3081

Pennisi E., 2010. Sowing the seeds for the ideal crop. Science 327, 802-803

Peters C.J., Wilkins J.L., Fick G.W., 2007. Testing a complete-diet model for estimating the land resource requirements of food consumption and agricultural carrying capacity: The New York State example. Renewable Agr. Food Syst. 22, 145-153
Peters G.M., Rowley H.V., Wiedemann S., Tucker R., Short M.D., Schulz M., 2010. Red meat production in Australia: life cycle assessment and comparison with overseas studies. Environ. Sci. Technol. 44, 1327-1332

Pimentel D., Pimentel M., 2003. Sustainability of meat-based and plant-based diets and the environment. Amer. J. Clin. Nutr. 78, 660S-663S

Post M.J., 2014. An alternative animal protein source: cultured beef. Ann. NY Acad. Sci. 1328, 29-33

Powell J.M., MacLeod M., Vellinga T.V., Opio C., Falcucci A., Tempio G., Steinfeld H., Gerber P., 2013. Feed-milk-manure nitrogen relationships in global dairy production systems. Livest. Sci. $152,261-272$

Ranga Niroshan Appuhamy J.A.D., Strathe A.B., Jayasundara S., Wagner-Riddle C., Dijkstra J., France J., Kebreab E., 2013. Anti-methanogenic effects of monensin in dairy and beef cattle: a meta-analysis. J. Dairy Sci. 96, 5161-5173

Remling N., Riede S., Lebzien P., Meyer U., Höltershinken M., Kersten S., Breves G., Flachowsky G., Dänicke S., 2014. Effects of fumaric acid on rumen fermentation, milk composition and metabolic parameters in lactating cows. J. Anim. Physiol. Anim. Nutr. 98, 968-981

Reynolds C.K., Humphries D.J., Kirton P., Kindermann M., Duval S., Steinberg W., 2014. Effects of 3-nitrooxypropanol on methane emission, digestion, and energy and nitrogen balance of lactating dairy cows. J. Dairy Sci. 97, 3777-3789

Reynolds M.P. (Editor), 2010. Climate Change and Crop Production. CAB International. Wallingford (UK), pp. 292

Ricci P., Rooke J.A., Nevison I., Waterhouse A., 2013. Methane emissions from beef and dairy cattle: quantifying the effect of physiological stage and diet characteristics. J. Anim. Sci. 91, 5379-5389

Roer A.G., Johansen A., Bakken A.K., Daugstad K., Fystro G., Stromman A.H., 2013. Environmental impacts of combined milk and meat production in Norway according to a life cycle assessment with expanded system boundaries. Livest. Sci. 155, 384-396

Romero Perez A., Beauchemin K.A., Okine E.K., Duval S.M., 2013. Effects of 3-nitrooxipropanol on methane production using the rumen simulation technique (Rusitec). Adv. Anim. Biosci. 4, 389 (Abstr.)

Rounsevell M.D.A., Pedroli B., Erb K.H. et al., 2012. Challenges for land system science. Land Use Policy 29, 899-910

Ruane J., Dargie J.D., Mba C., Boettcher P., Makkar H.P.S., Bartley D.M., Sonnino A., 2013. Biotechnologies at work for smallholders: case studies from developing countries in crops, livestock and fish. Occasional papers on "Innovation in Family Farming". FAO, Rome, pp.198

Rumpold B.A., Schlüter O.K., 2013. Nutritional composition and safety aspects of edible insects. Mol. Nutr. Food Res. 57, 802-823

Ruttan V.W., 1999. The transition to agricultural sustainability. Proc. Nat. Acad. Sci .USA 96, 5960-5967

SAFA (Sustainable Assessment of Food and Agriculture), 2013. SAFA Indicators. FAO, Rome. Available online at http://www.fao. org/fileadmin/templates/nr/sustainability_pathways/docs/ SAFA_Indicators_final_19122013.pdf

Sanchez-Muros M.J., Barroso F.G., Manzano-Agugliaro F., 2014. Insect meal as renewable source of food for animal feeding: a review. J. Clean. Prod. 65, 16-27

SCAR (Standing Committee on Agricultural Research), 2008. New Challenges for Agricultural Research. Climate Change, Rural Development, Agricultural Knowledge Systems. The $2^{\text {nd }}$ SCAR Foresight Exercise. European Commission, Brussels (Belgium), pp. 112 
Schlink A.C., Nguyen M.L., Viljoen G.J., 2010. Water requirements for livestock production: a global perspective. Rev. Sci. Tech. 29 , 603-619

Scholz R.W., Wellmer F.W., 2013. Approaching a dynamic view on the availability of mineral resources: What we may learn from the case of phosphorus? Global Environ. Change 23, 11-27

Smil V. (Editor), 2000. Feeding the World: A Challenge for the Twenty-First Century. The MIT Press. Cambridge, MA (USA), pp. 390

Smith J., Sones K., Grace D., MacMillan S., Tarawali S., Herrero M., 2013a. Beyond milk, meat, and eggs: role of livestock in food and nutrition security. Anim. Front. 3, 6-13

Smith P., Gregory P.J., van Vuuren D., Obersteiner M., Havlik P., Rounsevell M., Woods J., Stehfest E., Bellarby J., 2010. Competition for land. Philos. Trans. Roy. Soc. London, 365, 2941-2957

Smith P., Haberl H., Popp A. et al., 2013b. How much land-based greenhouse gas mitigation can be achieved without compromising food security and environmental goals? Global Change Biol. 19, 2285-2302

Souci S.W., Fachmann W., Kraut H., 2008. Food table for the practice. The little Souci-Fachmann-Kraut (in German). $7^{\text {th }}$ Edition. Deutsche Forschungsanstalt für Lebensmittelchemie. Freising, Wiss.Verlagsgesellschaft mbH. Stuttgart (Germany), pp. 1364

Speijers G., Bottex B., Dusemund B., Lugasi A., Tóth J., AmbergMüller J., Galli C.L., Silano V., Rietjens I.M.C.M., 2010. Safety assessment of botanicals and botanical preparations used as ingredients in food supplements: Testing an European Food Safety Authority-tiered approach. Mol. Nutr. Food Res. 54, 175-185

Stevens R.J., Laughlin R.J., Burns L.C., Arah J.R.M., Hood R.C., 1997. Measuring the contributions of nitrification and denitrification to the flux of nitrous oxide from soil. Soil Biol. Biochem. 29, 139-151

Strzepek K., Boehlert B., 2010. Competition for water for the food system. Philos. Trans Roy. Soc. London B 365, 2927-2940

Tester M., Langridge P., 2010. Breeding technologies to increase crop production in a changing world. Science $327,818-822$

The Royal Society, 2009. Reaping the benefits: Science and the sustainable intensification of global agriculture. The Royal Society Policy, document 11/09, issued Oct. 2009, RS1608

Thompson B., Amoroso L. (Editors), 2014. Improving Diets and Nutrition: Food-based Approaches. FAO and CAB International. Wallingford (UK), pp. 403

Thornton P.K., 2010. Livestock production: recent trends, future prospects. Philos. Trans Roy. Soc. London B 365, 2853-2867

Tillie P., Dillen K., Rodriguez-Cerezo E., 2013. The pipeline of GM crops for improved animal feed: challenges for commercial use. In: G. Flachowsky (Editor). Animal Nutrition with Transgenic Plants. CAB International, Wallingford (UK), pp. 166-192

Upham P., Dendler L., Bleda M., 2011. Carbon labelling of grocery products: public perceptions and potential emissions reductions. J. Clean. Prod. 19, 348-355

Van Eenennaam A.L., Young A.E., 2014. Prevalence and impacts of genetically engineered feedstuffs on livestock populations. J. Anim. Sci. 92, 4255-4278 van der Spiegel M., Noordam M.Y., van der Fels-Klerx H.J., 2013. Safety of novel protein sources (insects, microalgae, seaweed, duckweed, and rapeseed) and legislative aspects for their application in food and feed production. Compr. Rev. Food Sci. Food Saf. 12, 662-678

van Huis A., 2013. Potential of insects as food and feed in assuring food security. Annu. Rev. Entomol. 58, 563-583

Van Soest P.J., 1994. Nutritional Ecology of the Ruminant. $2^{\text {nd }}$ Edition. Cornell University Press. Ithaca, NY (USA)

Vandehaar M.J., 1998. Efficiency of nutrient use and relationship to profitability on dairy farms. J. Dairy Sci. 81, 272-282

Vermeulen S.J., Campbell B.M., Ingram J.S.I., 2012. Climate change and food systems. Annu. Rev. Environ. Resour. 37, 195-222

Viljoen A., Wiskerke J.S.C. (Editors), 2012. Sustainable Food Planning: Evolving Theory and Practice. Wageningen Academic Publishers. Wageningen (the Netherlands), pp. 600

von Carlowitz H.C., 1713. Sylviculture Oeconomica, Anweisung zur wilden Baum-Zucht. Braun Verlag Leipzig, pp.105-106

Wals A.E.J., Corcoran P.B. (Editors), 2012. Learning for Sustainability in Times of Accelerating Change. Wageningen Academic Publishers. Wageningen (the Netherlands), pp. 550

Wennemer H., Flachowsky G., Hoffmann V., 2006. Protein, Population, Politics - How Protein can be Supplied Sustainable in the $21^{\text {st }}$ century. Plexus Verlag. Mittenberg and Frankfurt/Main, pp. 160

WHO/FAO/UNU, 2007. Protein and amino acid requirements in human nutrition. Report of a joint FAO/WHO/UNU expert consultation. World Health Organization United Nations University. WHO Technical Report Series 935, pp. 265

Williams A.G., Audsley E., Sanders D.L., 2006. Determining the environmental burdens and resource use in the production of agricultural and horticultural commodities. Main Report. Defra Research Project IS0205, Bedford: Cranfield University and Defra, pp. 97. Available on www.silsoe.cranfied.ac.uk, and www.defra.gov.uk

Wirsenius S., Azar C., Berndes G., 2010. How much land is needed for global food production under scenarios of dietary changes and livestock productivity increases in 2030? Agr. Syst. 103, 621-638

Wu G., Bazer F.W., Cross H.R., 2014a. Land-based production of animal protein: impacts, efficiency, and sustainability. Ann. NY Acad. Sci. 1328, 18-28

Wu G., Fanzo J., Miller D.D., Pingali P., Post M., Steiner J.L., Thalacker-Mercer A.E., 2014b. Production and supply of high-quality food protein for human consumption: sustainability, challenges, and innovations. Ann. NY Acad. Sci. 1321, 1-19

Young W., Hwang K., McDonald S., Oates C.J., 2010. Sustainable consumption: green consumer behaviour when purchasing products. Sustain. Dev. 1, 20-31

Zehetmeier M., Baudracco J., Hoffmann H., Heißenhuber A., 2012. Does increasing milk yield per cow reduce greenhouse gas emissions? A system approach. Animal 6, 154-166

Zepka L.Q., Jacob-Lopes E., Goldbeck R., Souza-Soares L.A., Queiroz M.I., 2010. Nutritional evaluation of single-cell protein produced by Aphanothece microscopica Nägeli. Bioresource Technol. 101, 7107-7111 